\title{
Temporal dynamics of sucking pest and field response of promising insecticidal molecules in okra
}

\author{
Tamoghna Saha ${ }^{1 *}$, Mohmmad Ansar ${ }^{2}$, C. Nithya ${ }^{3}$, and S. N. Ray ${ }^{1}$ \\ ${ }^{1}$ Department of Entomology, , Bihar Agricultural University, Sabour, Bhagalpur-813210 (Bihar), INDIA \\ ${ }^{2}$ Department of Plant Pathology, Bihar Agricultural University, Sabour, Bhagalpur-813210 (Bihar), INDIA \\ ${ }^{3}$ Division of Entomology, India Agricultural Research Institute (IARI), New Delhi-110012, INDIA \\ *Corresponding author. E-mail: tamoghnasaha1984@gmail.com
}

Received: July 13, 2015; Revised received: November 11, 2015; Accepted: March 11, 2016

\begin{abstract}
To investigate the response due to application of newer insecticide on sucking pest in okra, a trial was designed at field level for three consecutive years from 2011-12 to 2013-14 in kharif season. Moreover, impacts of applied insecticides on natural enemies were also assessed. Based on experimental finding thiamethoxam 25WG $0.003 \%$ (2.83 per 3 leaves, 0.93 per 3 leaves), imidacloprid 70WG $0.004 \%$ (3.49 per 3 leaves, 1.30 per 3 leaves) and thiacloprid 21.7 SC $0.006 \%$ (4.28 per 3 leaves, 1.75 per 3 leaves) provided superior control of leafhoppers and whiteflies population on okra. Effectiveness of these treatments was reflected in terms of reduction in population of both insects and significantly increases (thiamethoxam: $95.50 \mathrm{q} / \mathrm{ha}$, imidacloprid: $86.96 \mathrm{q} / \mathrm{ha}$ and thiacloprid: 80.99 $\mathrm{q} / \mathrm{ha}$ ) the fruit yield in comparison to others. However, the incidence of Yellow Vein Mosaic disease was recorded least in thiamethoxam $0.003 \%$ sprayed plots followed by imidacloprid $0.004 \%$. Slow progress in the population of whitefly and leaf hopper was recorded in thiamethoxam $0.003 \%$ applied plots. There was positive correlation between whitefly and virus incidence in conducted field trial. Under the experiment, neonicotinoids group of insecticides have not adverse effect on natural enemies in okra crop. The information generated under the study can be incorporated in management modules in crop okra without disturbing the ecology of natural enemy and cropping system. In our findings, the quantitative data of temporal increment of whiteflies and mosaic disease will be helpful in understanding or formulating of epidemiological models.
\end{abstract}

Keywords: Insecticides, Leafhoppers, Natural enemies, Okra, Whiteflies

\section{INTRODUCTION}

Okra (Abelmoschus esculentus L. Monech), commonly recognized as "Bhendi", is cultivated all over India. It occupies an area of about 5, 32,000 ha with production of 6346 million tones and productivity of 11.90 metric ton/ha in India. In Bihar, it occupies 58, 000 ha with production of 783.54 million tones and productivity of 3.50 metric ton/ha (NHB, 2014).

The productivity of okra is low due to many factors and Insect pests are one of the major limiting factors for lower productivity. As high as 72 species of insects have been documented on okra (Srinivasa and Rajendran, 2003), of which, the sucking pests comprising of leafhopper, Amrasca biguttula biguttula (Ishida), whitefly, Bemisia tabaci (Gennadius) and mite, Tetranychus cinnabarinus (Boisduval) causes significant damage to the crop. The sucking pest complex (aphids, leaf hoppers, whiteflies, and mites) of okra cause $17.46 \%$ yield loss and failure to control them in initial stages was reported to cause $54.04 \%$ yield loss (Chaudhary and Daderch, 1989 and Anitha and Nandihalli, 2008). The cultivation of okra in India obtained a drawback due to yellow vein mosaic virus (YVMV) and enation leaf curl virus (ELCV), transmitted by the vector ISSN : 0974-9411 (Print), 2231-5209 (Online) All Rights Reserved (C) Applied and Natural Science Foundation www.ansfoundation.org whitefly. Marketable yield loss has been estimated at $50-94 \%$, depending up on the stage of crop growth at which the infection occurs (Chaudhary and Dadeech, 1989). In order to overcome sucking pest problem, using various agro-techniques in combination with selective use of insecticides. Moreover, applied newer combination on non target organisms (Coccinellids, spiders and chrysoperla) and their responses were also studied. The designed experiment on sucking pest associated with okra crop will be a good management option without harming the ecology of beneficial predatory insects. Additionally, the trends of insect population along with associated disease provide a prediction about the damage accordingly need base application may be suggested.

\section{MATERIALS AND METHODS}

Location of experiment: The present investigation was conducted at the All India Coordinated Research Project Vegetable Research Centre, Sabour (latitude $87^{\circ} 2^{\prime} 54^{\prime \prime E}$, longitude $25^{\circ} 14^{\prime} 24^{\prime \prime} \mathrm{N}$, altitude 30 AMSL), Bhagalpur, Bihar.

Field experiment and insecticidal application: The trial was laid out with eight treatments including check 
in a randomized block design in plots of $5 \mathrm{~m} \times 3 \mathrm{~m}$ and spacing of $60 \mathrm{~cm} \times 45 \mathrm{~cm}$ during kharif season of 2011 $-12,2012-13$ and 2013-14 and replicated thrice. The seedlings of okra, variety Kashi Pragati, were raised on $10^{\text {th }}$ June $2011-12,15^{\text {th }}$ June $2012-13$ and $12^{\text {th }}$ June 2013-14 and crops were raised as per recommended package of practices except insect-pest management practices. The treatments comprised of seven insecticides viz. $\mathrm{T}_{1}$-thiamethoxam $25 \mathrm{WG} \mathrm{@} \mathrm{0.003 \%}$ (Actara $^{\circledR}$, Syngenta), $\mathrm{T}_{2}$-imidacloprid 70WG 0.004\% (Admire $^{\circledR}$, Bayer crop Science Ltd), $\mathrm{T}_{3}$-Spiromesifen 22.9 SC@0.023\% (Oberon ${ }^{\circledR}$, Bayer Crop Science), $\mathrm{T}_{4}$ -buprofezin 25 SC@0.025\% (Applaud ${ }^{\circledR}$, Rallis India Limited), $\mathrm{T}_{5}$-diafenthiuron 50 WP @ $0.05 \%$ (Pegasus $^{\circledR}$, Syngenta), T 6 -dimethoate 30 EC @ 0.03\% (Rogor $^{\circledR}$, Cheminova India Ltd), $\mathrm{T}_{7}$-thiacloprid 21.7 SC@ $0.006 \%$ (Splendour ${ }^{\circledR}$, Cheminova India Ltd) at recommended doses along with an $\mathrm{T}_{8}$-untreated check were taken to test their effect on sucking pest of okra. Three sprays were given at fortnightly interval started from 20 Days after sowing. All the formulations were procured from local market. After built up of uniform leafhopper and whitefly population in the field, three sprays at fortnight interval were given with a pneumatic knack sac sprayer with a spray fluid volume of 500 L ha- ${ }^{1}$.

Methodology: The pretreatment count and post treatment observations on leafhopper and whitefly population at 1,7 and 14 days after spraying were recorded from three leaves per plant, one each from top, middle and bottom. Five plants per plot were selected at random leaving border rows during pre-treatment observation and subsequent data were recorded from those selected plant. Natural enemy observations were taken randomly selected five plants per plot. Okra green fruits were collected at each picking and weighed separately from each net plot area. At the end of last picking, total yield from each net plot was calculated and computed on hectare basis $(\mathrm{q} / \mathrm{ha})$. Yield increase $(\%)$ in different treatments over untreated check was calculated using the following formula:

Increase (\%) - Treatment yield-Control yield $\times 100$ Treatment yield

Temporal pattern of leaf hopper and whitefly: To assess the pattern of both sucking insects over the period of time, the population was recorded 15 days after emergence (DAE), 25 DAE, 35-DAE, 45-DAE and 55DAE. To record the population followed the above described methodology in each treatment.

Relationship between whitefly and yellow vein mosaic: In respect of each insecticide application, the population of whitefly and incidence of yellow vein mosaic was recorded. The linear regression equation of whitefly and yellow vein mosaic was defined and graph was constructed using Microsoft Excel software.

Statistical treatment: Data obtained were subjected to analysis of variance (ANOVA) after appropriate transformation according to Gomez and Gomez (1984).
Benefit cost analysis for different insecticides: The following parameters were used:

Cost of okra fruits: Rs 800 q-1; number of labourers required per spray ha-1: 2; labour charges: Rs 176 day1, Cost of insecticides: thiamethoxam25 WG @ Rs. $2025 \mathrm{~kg}^{-1}$, imidacloprid $70 \mathrm{WG} @$ Rs. $1144 \mathrm{~kg}^{-1}$, Spiromesifen 22.9 SC @ Rs. $3800 \mathrm{~L}^{-1}$, buprofezin 25 SC@Rs $1380 \mathrm{~L}^{-1}$, diafenthiuron50 WP@ Rs.4040 $\mathrm{kg}^{-1}$, dimethoate $30 \mathrm{EC} @$ Rs.450 L ${ }^{-1}$ and thiacloprid 21.7 SC@Rs.2093 kg-1.

\section{RESULTS AND DISCUSSION}

Leafhopper infestation: The data presented in Table 1 , clearly depicted that all the insecticidal treatments were effective against the leafhopper, though varied their efficacies ( 2.83 to 5.16 per 3 leaves) and significantly superior over untreated check (11.86 per 3 leaves). The data showed that minimum (2.83 per 3 leaves, $76.13 \%$ ) leafhoppers population was recorded in thiamethoxam $0.003 \%$ followed by imidacloprid $0.004 \%$ (3.49 per 3 leaves, 70.57\%), thiacloprid $0.006 \%$ (4.28 per 3 leaves, $63.91 \%$ ) and buprofezin $0.025 \%$ (4.31 per 3 leaves, 63.65\%). Moreover, comparatively higher population was recorded with diafenthiuron $0.05 \%$ (5.44 per 3 leaves, $54.13 \%$ ) and dimethoate $0.03 \%$ (5.16 per 3 leaves, $56.49 \%$ ). Our eexperimental results clearly stated that thiamethoxam and imidacloprid were the most effective in reduction of 76.13 and $70.57 \%$ leafhoppers population respectively. These findings are in conformity with the earlier finding of Patil et al.(2014) and they reported that thiamethoxam 25 WG@0.006\% was effective against leafhoppers population after thiamethoxam 25 WG@ $0.008 \%$. In earlier finding of Sinha and Sharma (2007), the foliar spray of thiamethoxam25 WG@20 $\mathrm{g}$ a.i./ha at 30 days of sowing was found effective in managing leafhopper (Amrasca biguttula biguttula) population on okra. Similarly, Anitha and Nandihalli (2009) reported that imidacloprid 70 WS and thiamethoxam 70 WS were significantly superior over all other untreated plots at 25, 35 and 45 days after sowing.

Whitefly infestation: The population of Whitefly was varied from 0.93 to 9.85 per 3 leaves (Table 1). The least ( 0.93 per 3 leaves, $90.55 \%$ ) population of whitefly was observed in thiamethoxam $0.003 \%$ after imidacloprid $0.004 \%$ (1.30 per 3 leaves, $86.80 \%$ ) which was not significantly differed. Second important treatment, thiacloprid $0.006 \%$ (1.75 per 3 leaves, $82.23 \%$ ) followed by spiromesifen $0.023 \%$ (2.27 per 3 leaves, $75.95 \%$ ). Among applied tratments, Maximum number of whiteflies were noticed in diafenthiuron $0.05 \%$ (3.00 per 3 leaves, 69.54\%) and dimethoate $0.03 \%$ (3.49 per 3 leaves, $64.56 \%$ ). On the basic of whitefly infestation, all the insecticidal treatments were significantly superior over control, whereas thiamethoxam $0.003 \%$ found promising to reduce the whitefly. Our earlier studies supported the findings of Rohini et al. (2012) who reported that thiamethoxam 5 


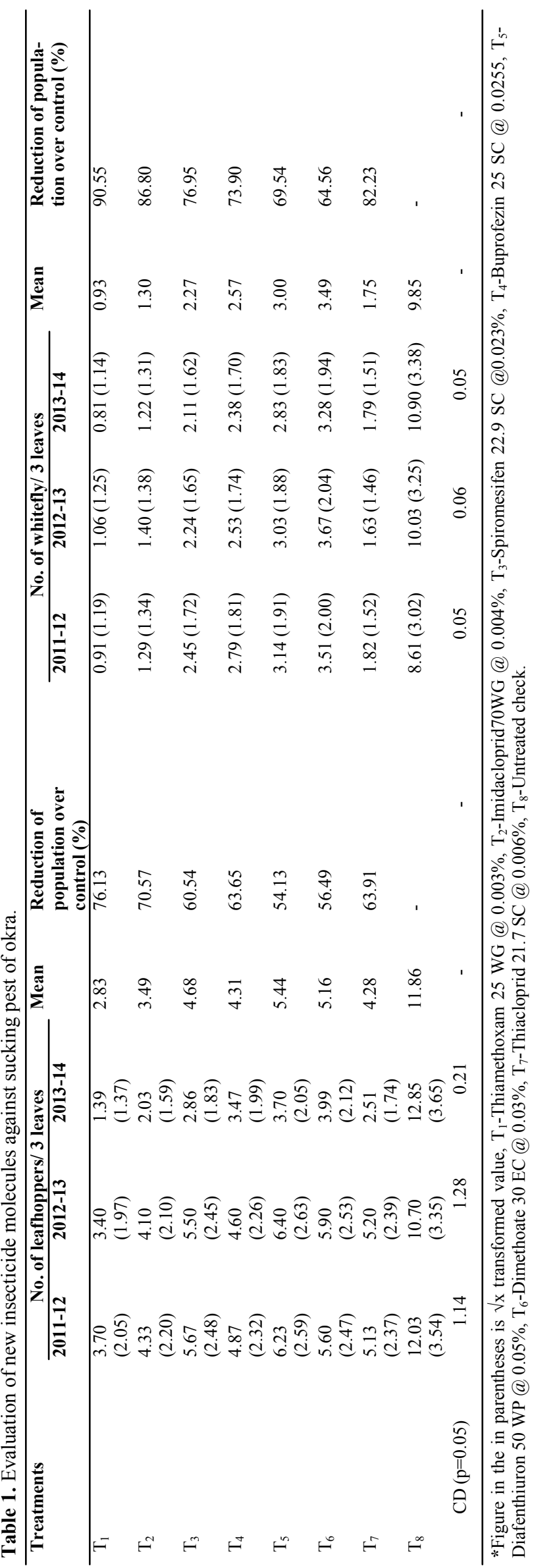

SG@ 0.2 g/l was effective in reducing whiteflies population compared to untreated control. Mohanasundaram and Sharma (2011) also reported the effectiveness of thiamethoxam 25 WG against whitefly in okra. Among the different chemical tested in field condition, imidacloprid @200 ml/acre was found to be most effective (1.97 per 3 leaves) in reduction of whitefly population in okra (Ali et al., 2012).

Temporal pattern of leafhopper and whitefly: In this experiment pattern of population was studied due to application of insecticides. The number of leaf hopper per 3 plants was recorded at 10 days after emergence (DAE). The maximum population of leaf hopper (9.9) was recorded in 45-DAE of unsprayed plots, however, the peak of white fly population (10.7) at same interval (Fig. 1). Slow progress in the population in both insects was recorded in thiamethoxam sprayed plots. At 15-DAE there was not any population noticed in thiamethoxam and imidacoprid sprayed plots. The trend of increment in both insect populations noticed slowly in insecticide sprayed plots. Among the applied treatments, dimethoate used plots having increasing trend after untreated check. The maximum population (3.9) in whitefly, and in leaf hopper (3.6) at 45-DAE noticed. Kumar et al. (2001) studied efficacy of imidacloprid and thiamethoxan on okra against leafhopper and whitefly population. His experiment proves various doses of imidacloprid and thiamethoxan had no phototoxic effect on okra but effective against insects. In given context, our findings provide evidence of reduction in population of both sucking pests. As the earlier findings of Singh et al. (2013), there was no infestation of whiteflies in the month of August (34th and 36th standard weeks). The incidence commenced from the 3rd week after sowing that is, first fortnight of September with an average population level of $0.1 /$ leaf. The gradual increment in the population reached the peak level of 12.4 /leaf during fourth week of September. However, the leafhopper appeared in the fourth week of August with an average population of 1.2 /leaf. The population reached the peaked in the fourth week of October (18.43/leaf).

Relationship between whitefly and yellow vein mosaic: Under the study of relationship between whitefly and yellow vein mosaic disease, a positive correlation was observed. The linear regression equation $\left(\mathrm{y}=2.990 \mathrm{x}+19.48 r^{2} 0.8620\right)$, represent that more than $80 \%$ influence in yellow vein mosaic by whitefly population (Fig. 2). The present finding linking to the investigation of Ansar et al., (2014), the multiple determinations $R^{2}$ value (0.970) represents that $97 \%$ influence in the population of whiteflies by five abiotic factors which is vector of $Y V M V$. Moreover, in his study various cultivar of okra like, VRO-6, 'Pusa Sawni' and Sonachi, showed positive relationship of whiteflies and viral incidence. The $R^{2}$ value $(0.701)$ represents for 'Pusa Sawni' which was close relationship among vector and disease incidence. The $R^{2}$ value 
Table 2: Yield and economics of different insecticides in okra.

\begin{tabular}{|c|c|c|c|c|c|c|c|c|}
\hline \multirow{2}{*}{$\begin{array}{l}\text { Treat- } \\
\text { ments }\end{array}$} & \multicolumn{3}{|c|}{ Yield (q/ha) } & \multirow{2}{*}{$\begin{array}{l}\text { Mean } \\
\text { Yield } \\
\text { (q/ha) }\end{array}$} & \multirow{2}{*}{$\begin{array}{l}\text { Per cent } \\
\text { increase in } \\
\text { yield over } \\
\text { control } \\
\end{array}$} & \multirow{2}{*}{$\begin{array}{l}\text { Gain in yield } \\
\text { over control } \\
\text { (q/ha) }\end{array}$} & \multirow[t]{2}{*}{ Net Gain } & \multirow{2}{*}{$\begin{array}{l}\text { Benefit: } \\
\text { Cost } \\
\text { ratio }\end{array}$} \\
\hline & 2011-12 & 2012-13 & 2013-14 & & & & & \\
\hline $\mathrm{T}_{1}$ & 93.38 & 98.00 & 95.11 & 95.50 & 56.45 & 34.46 & 25870.33 & 16.26 \\
\hline $\mathrm{T}_{2}$ & 86.22 & 88.22 & 86.44 & 86.96 & 42.46 & 25.92 & 19186.00 & 13.38 \\
\hline $\mathrm{T}_{3}$ & 75.27 & 79.44 & 75.89 & 76.87 & 25.93 & 15.83 & 10351.33 & 5.48 \\
\hline $\mathrm{T}_{4}$ & 82.07 & 85.84 & 72.33 & 80.08 & 31.19 & 19.04 & 13048.00 & 6.97 \\
\hline $\mathrm{T}_{5}$ & 70.44 & 74.67 & 70.22 & 71.78 & 17.6 & 10.74 & 375.33 & 1.05 \\
\hline $\mathrm{T}_{6}$ & 71.00 & 72.78 & 67.67 & 70.48 & 15.47 & 9.44 & 5014.66 & 2.97 \\
\hline $\mathrm{T}_{7}$ & 79.60 & 81.38 & 82.00 & 80.99 & 32.68 & 19.95 & 14677.67 & 12.42 \\
\hline $\mathrm{T}_{8}$ & 60.89 & 62.67 & 59.56 & 61.04 & - & - & - & - \\
\hline $\begin{array}{l}C D \\
(p=0.05)\end{array}$ & 1.14 & 9.37 & 18.54 & - & - & - & - & - \\
\hline
\end{tabular}

T1-Thiamethoxam 25 WG @ 0.003\%, T2-Imidacloprid70WG@0.004\%, T3-Spiromesifen 22.9 SC @0.023\%, T4-Buprofezin 25 SC@0.0255, T5-Diafenthiuron 50 WP@0.05\%, T6-Dimethoate 30 EC@0.03\%, T7-Thiacloprid 21.7 SC@0.006\%, T8Control.

(0.701) represents for 'Pusa Sawni' which was close relationship among vector and disease incidence.

Safety to non target organisms: The safety of the treatments to predatory coccinellids, spiders and grubs of chrysoperla was one of the important factors to be taken into account (Table 3). Based on three years observation on the mean population of coccinellids, spiders and chrysoperla grubs indicated that all the new molecules were safer to the predator by recording 0.50 to 0.83 coccinellids per plant, 0.55 to 0.89 spiders' per plant and 0.60 to 0.87 chrysoperla grubs per plant except dimethoate $0.03 \%$. The control invariably gave a much higher count of each of these. Experimental results clearly stated that neonicotinoids group of insecticides were safer to natural enemies (coccinellids, spiders and chrysoperla grubs). The present findings are in conformity with Ghosal et al. (2013) and found that none of the neonicotinoids have adverse effect on natural enemies in okra ecosystem. Sun et al. (1996) reported that imidacloprid was safe for spider communities.

Economics of different insecticides: The data presented in Table 2 indicated that all the insecticidal treatments recorded increase in marketable yield over untreated check. Thiamethoxam $0.003 \%$ recorded the highest marketable yield (95.50 q per ha), an increase in marketable yield of $56 \%$ and net profit Rs. 25870 . The next best treatments were imidacloprid $0.004 \%$ (86.96 q per ha, $42 \%$ and Rs. 19186), thiacloprid $0.006 \%$ (80.99 q per ha, 33\% and 14677) and buprofezin $0.025 \%$ (80.08 q per ha, $31 \%$ and Rs. 13048). The cost -benefit ratio (C:B ratio) calculated on the basis of cost of protection by different insecticidal treatments trended in descending order as: thiamethoxam $0.003 \%$ $(1: 16.26)>$ imidacloprid $0.004 \%(1: 13.38)>$ thiacloprid $0.006 \%(1: 12.42)>$ buprofezin $0.025 \%$. Experimental findings clearly stated that thiamethoxam $0.003 \%$, imidacloprid $0.004 \%$ and thiacloprid $0.006 \%$ recorded highest marketable yield, net profit and cost-benefit ratio as compared to other treatments. These three insecticides come under neonicotinoid group and they showed better yield and highest $\mathrm{C}: \mathrm{B}$ ratio than others. Venkataravanappa et al. (2012) proved that thiamethoxam $25 \mathrm{WG}$ gave highest fruit yield of okra. Similarly, Anitha and Nandihalli (2009) reported that imidacloprid $200 \mathrm{SL}(47.71 \mathrm{q} / \mathrm{ha})$ and thiamethoxam 70 WS (44.10 q/ha) registered highest fruit yield in okra. Similarly, Patil et al.(2014) reported that highest

Table 3. Influence of new molecules on the occurrence of natural enemies in okra (Pooled value of three years).

\begin{tabular}{llll}
\hline Treatments & Coccinellids (No./plant) & Spiders (No./plant) & Chrysoperla grubs (No./plant) \\
\hline $\mathrm{T}_{1}$ & $0.83(1.15)$ & $0.89(1.15)$ & $0.87(1.17)$ \\
$\mathrm{T}_{2}$ & $0.80(1.14)$ & $0.80(1.18)$ & $0.80(1.14)$ \\
$\mathrm{T}_{3}$ & $0.50(1.00)$ & $0.60(1.04)$ & $0.68(1.08)$ \\
$\mathrm{T}_{4}$ & $0.50(1.00)$ & $0.66(1.07)$ & $0.70(1.09)$ \\
$\mathrm{T}_{5}$ & $0.60(1.04)$ & $0.55(1.02)$ & $0.60(1.05)$ \\
$\mathrm{T}_{6}$ & $0.20(0.83)$ & $0.16(0.81)$ & $0.52(1.01)$ \\
$\mathrm{T}_{7}$ & $0.80(1.13)$ & $0.86(1.16)$ & $0.76(1.12)$ \\
$\mathrm{T}_{8}$ & $0.93(1.19)$ & $0.92(1.17)$ & $0.93(1.20)$ \\
$\mathrm{S} . \mathrm{Em} \pm$ & 0.05 & 0.05 & 0.04 \\
C.D $(\mathrm{p}=0.05)$ & 0.15 & 0.16 & 0.13 \\
\hline
\end{tabular}

*Figure in the in parentheses is $\sqrt{\mathrm{x}}$ transformed value, T1-Thiamethoxam 25 WG @ 0.003\%, T2-Imidacloprid70WG @ 0.004\%, T3-Spiromesifen 22.9 SC@0.023\%, T4-Buprofezin 25 SC @ 0.0255, T5-Diafenthiuron 50 WP @ 0.05\%, T6-Dimethoate 30 EC@0.03\%,T7-Thiacloprid21.7 SC@0.006\%,T8-Control. 

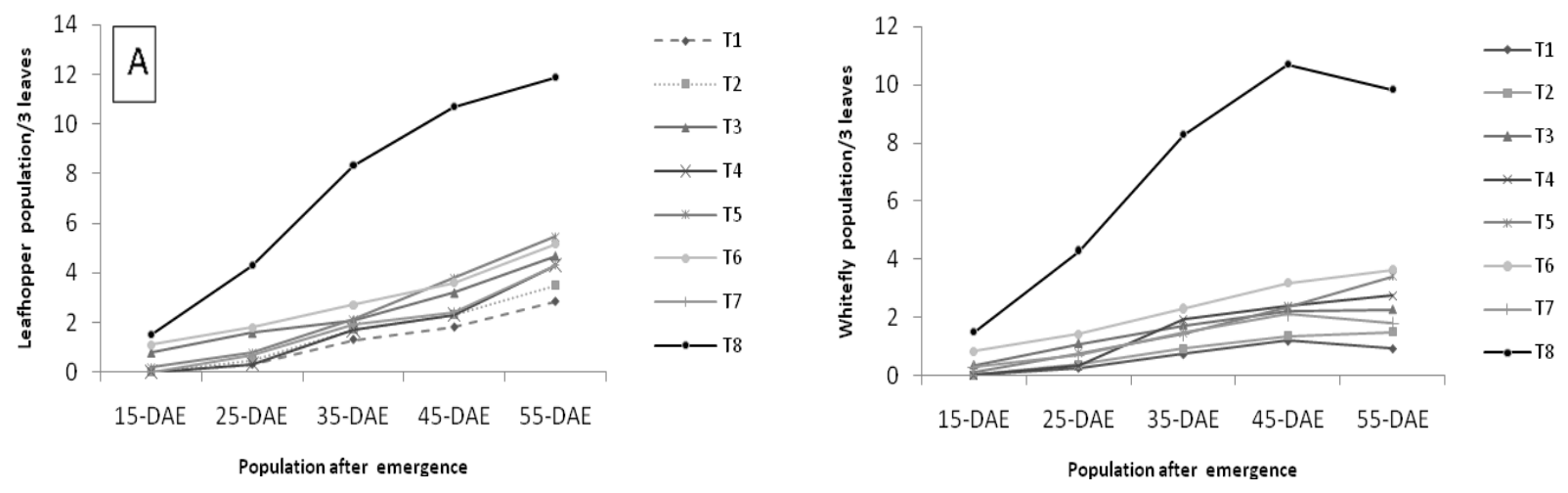

Fig. 1. Temporal progress of leaf hopper and whitefly in each insectide sprayed plots over period of time

yield of okra fruits $(66.05 \mathrm{q} / \mathrm{ha})$ was obtained from thiamethoxam 25 WG@0.006\% followed by the treatments thiamethoxam 25 WG@0.008\% and thiamethoxam 25WG@0.009\% which were at par with each other. However, Saha et al. (2011); Kencharaddi and Balikai (2012) also reported neonicotinoids (imidacloprid, thiamethoxam) as better option for managing various sucking pests with higher $\mathrm{C}$ : $\mathrm{B}$ ratio.

\section{Conclusion}

The sucking insect-pest is one of the major problems for wide plant species across the globe. Among them whiteflies and leafhoppers not only feeding on plants but they are the great vector of virus. Our present study is a step towards eco-friendly management of both deadly sucking insects in okra cropping system. In our findings, thiamethoxam and imidacloprid reduces the more than $70 \%$ population. Therefore, this might be potential pesticides for controlling leafhoppers and whiteflies in okra and simultaneously it shows safer to natural enemies and recorded highest yield and cost benefit ratio than others. Additionally, that improved the production with highest cost benefit ratio than others. Therefore, the selected newer pesticides may be incorporated in integrated pest management modules.

\section{ACKNOWLEDGEMENTS}

The authors are thankful to All India Coordinated Research Project (AICRP), Varanasi for providing financial grant (Rs. 1.00 lakh) to carry out the research work. The author would like to thank Bihar Agricultural University for providing facilities during the course of study.

\section{REFERENCES}

Ali, M.I. Khan, M.A. Abdul Rashid, Ehetisham-ul-haq, M. Javed, M.T. and Sajid, M. (2012). Epidemiology of okra yellow vein mosaic virus (OYVMV) and Its Management through Tracer, Mycotal and Imidacloprid. Am. J. Plant Sci. 3: 1741-1745

Anitha, K.R. and Nandihalli, B.S. (2008). Utilization of bo-

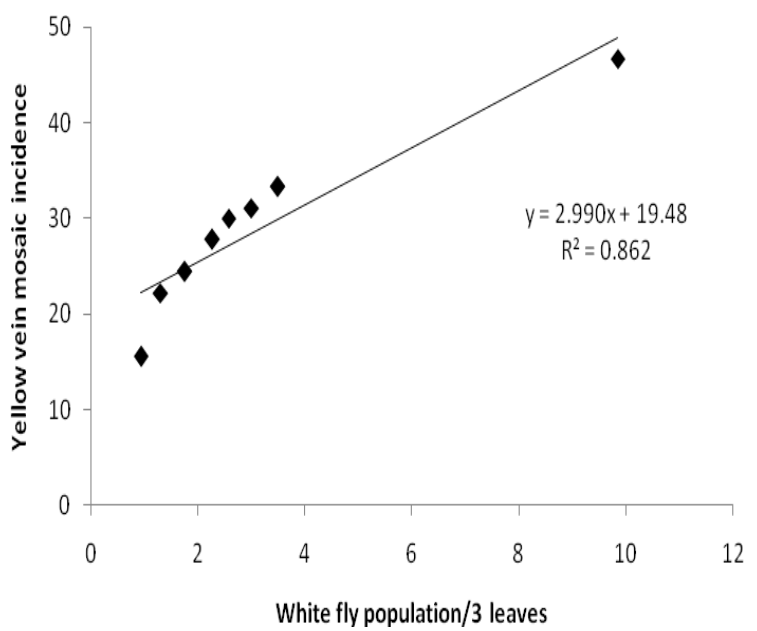

Fig. 2. Relationship between whitefly and yellow vein mosaic.

tanicals and mycopathogens in the management of sucking pests of okra. Karnataka J. Agric. Sci. 21(2): 231-233.

Anitha, K.R. and Nandihalli, B.S. (2009). Bioefficacy of newer insecticides against leafhopper and aphid in okra. Karnataka J. Agric. Sci. 22(3): 714-715.

Ansar, M. Saha, T. Sarkhel, S. and Bhagat, A.P. (2014). Epidemiology of okra yellow vein mosaic disease and its interaction with insecticide modules. Trend Biosci. 7 (24): 4157-4160.

Chaudhary, H.R. and Daderch, L.N. (1989). Incidence of insects attacking okra and the avoidable losses caused by them. Ann. Arid zone, 28: 305-07.

Ghosal, A. Chatterjee, M.L. and Bhattacharyya, A. (2013). Bio-efficacy of neonicotinoids against Aphis gossypii Glover of okra. J. Crop Weed. 9(2):181-184.

Gomez, K.A. and Gomez, A.A. (1984). Statistical Procedures for Agricultural Research. John Wiley and Sons, New York.

Kencharaddi, A.V. and Balikai, R.A. (2012). Effect of imidacloprid and thiamethoxam treated stored seeds on sucking pests in sunflower. Ann. Pl. Protec. Sci. 20: 107-13.

Kumar, N.K.K. Mooratht, P.N.K. and Reddy, S.G.E. (2001). Imidacloprid and thiamethoxan for the control of okra leafhopper and Bemisia tabaci. Pest Manage. Hortic. 
Zool. 7: 117-123.

Mohanasundaram, A. and Sharma, R.K. (2011). Effect of newer pesticide schedules on the population of sucking pests and predators on okra. Pesticide Research J. 23 (1): 55-63.

NHB, National Horticulture Board, (2014). http:// www.nhb.gov.in/area-pro/NHB_Database_2015.pdf

Patil, S.R. Lande, G.K. Nikita, S. Awasthi and Barkhade, U. P. (2014). Effect of different doses of newer insecticides against sucking pests of okra. The Bioscan, 9(4): 15971600.

Rohini, A. Prasad, N.V.V.S.D. and Chalam, M.S.V. (2012). Management of major suckingpests in cotton by insecticides. Ann. Pl. Protec. Sci. 20(1): 102-106.

Saha, T. Patil, R.K. Basavanna, Shekhrappa, K. and Nithya, C. (2011). Evaluation of insecticides against Apion amplum under laboratory and field conditions. Ann. Pl. Protec. Sci. 19: 10-14.

Singh, Y. Jha, A. Verma, S. Misra, V.K. and Singh, S.S. (2013). Population dynamics of sucking insect pests and its natural enemies on okra agro-ecosystem in Chitrakoot region. African J. Agric. Research. 8(28): 38143819.

Sinha, S. R. and Sharma, R.K. (2007). Efficacy of neonicotinoids against okra insect pests. Pesticide Research J. 19 (1): 42-44.

Srinivasa, R. and Rajendran, R. (2003). Joint action potential of neem with other plant extracts against the leaf hopper Amrasca devastance (Distant) on okra. Pest Manage. Econ. Zool. 10: 131-136.

Sun, J.Z. Fan, J.C. Xia, L.R. Yang, J.S. and Shen, X.S. (1996). Studies on the insecticidal activity of imidacloprid and its application in paddy fields against the brown planthopper, Nilaparvata lugens (Homoptera: Delphacidae). Acta Entomol. Sin. 39: 37-45.

Venkataravanappa, V. Krishnareddy, M. Lakshinimarayanreddy, C.N. and Salil, J. (2012). Managament of okra YVM disease through neem product and insecticides. Ann. Pl. Protec. Sci. 19 (2): 487-488. 